\title{
Articulações entre o sensível e a linguagem em Lavoura arcaica ${ }^{1}$
}

\author{
Renato Cury Tardivo ${ }^{2}$ \\ Universidade São Marcos, São Paulo-SP, Brasil \\ Danilo Silva Guimarães
}

\begin{abstract}
Resumo: Literatura e cinema são dois modos de produção estética diferentes que encontram articulações claras em diversas produções culturais contemporâneas. Exploraremos a obra Lavoura arcaica, de Raduan Nassar, em sua intersecção com o filme de mesmo nome, dirigido por Luiz Fernando Carvalho. Para tanto nos aproximamos das concepções filosóficas de Merleau-Ponty e Bakhtin, cujas ideias sustentam uma dimensão de tensão inerente à relação comunicativa/perceptiva. A análise das obras selecionadas procura explicitar o percurso de mudança na trajetória das relações humanas ao se tentar integrar a diversidade de possibilidades expressivas em um campo de sentido.
\end{abstract}

Palavras-chave: fenomenologia, dialogismo, literatura brasileira, arte (psicologia).

\section{Connections between the sensible and the language in To the left of the father}

\begin{abstract}
Cinema and literature are two different ways of aesthetic production that are interconnected in many contemporary cultural oeuvres. We will investigate relations between the book To the left of the father, written by Raduan Nassar and the homonym film directed by Luiz Fernando Carvalho. For that purpose we selected philosophical conceptions of MerleauPonty and Bakhtin, which bear a field of tension that is inherent to communicative/perceptive relations. The analysis of chosen works intends to make explicit the course of change in the human relations trajectories. It implies the seek of integration among the diversity of expressive possibilities.
\end{abstract}

Keywords: phenomenology, dialogism, Brazilian literature, art (psychology).

\section{Articulaciones entre el sensible y el lenguaje en Labor Arcaica}

\begin{abstract}
Resumen: Literatura y cine son dos modos de producción estética distinctos que presentan claras articulaciones en diversas producciones culturales contemporáneas. Exploraremos el trabajo Labor arcaica, de Raduan Nassar, en su intersección con la película del mismo nombre, dirigida por Luiz Fernando Carvalho. Con este fin nos acercamos a los conceptos filosóficos de Merleau-Ponty y Bakhtin, cuyas ideas sostienen una dimensión de tensión inherente a la relación comunicativa / perceptiva. El análisis de las obras seleccionadas busca aclarar a los cambios en la trayectoria de las relaciones humanas cuando se trata de integrar a la diversidad de posibilidades expresivas en un campo de sentido.
\end{abstract}

Palabras clave: fenomenología, dialogismo, literatura brasileña, arte (psicología).

Literatura e cinema são dois modos de produção estética diferentes que encontram articulações claras em diversas produções culturais contemporâneas. Os dois registros podem contribuir para o enriquecimento do debate sobre a natureza humana ao explicitarem as vicissitudes do vir a ser em um contexto marcado, pela heterogeneidade de atores sociais, discursos e percepções. Um exemplo disso, que exploraremos com mais detalhes na segunda metade do artigo, é a obra Lavoura arcaica, do escritor paulista Raduan Nassar (2002), publicada originalmente em 1975, e a elaboração do filme em 2001, com mesmo nome, dirigido por Luiz Fernando Carvalho (2001/2005).

No campo das preocupações psicológicas, a articulação entre literatura e cinema nos leva a pensar em outra

\footnotetext{
1 Apoio: FAPESP. Os autores agradecem a colaboração do Prof. Dr. Nelson Coelho Júnior, do Instituto de Psicologia da USP - IPUSP, nas discussões que precederam a submissão do manuscrito. Este texto foi revisado seguindo Acordo Ortográfico da Língua Portuguesa (1990), em vigor a partir de $1^{\circ}$ de janeiro de 2009.

2 Endereço para correspondência:

Renato Cury Tardivo. Rua Gabrielle d'annunzio, 500. CEP 04.619-005.
}

São Paulo-SP, Brasil. E-mail: rctardivo@uol.com.br articulação, entre o sensível e a linguagem na experiência subjetiva, caracterizada pela integração dos sentidos na ação expressiva.

Ao focalizar a expressividade da ação, nos aproximamos de dois filósofos que se caracterizam pela proposta de ultrapassar as concepções racionalistas e empiristas da natureza humana e por insistirem fortemente na consideração da experiência concreta de vida dos sujeitos à compreensão de suas ações no mundo: Mikhail Bakhtin (1895-1975) e Maurice Merleau-Ponty (1908-1961).

A aproximação de Merleau-Ponty (1945/1994) com o pensamento fenomenológico foi intensa, servindo como base à composição de um pensamento que se confronta com o positivismo cientificista e com o subjetivismo filosófico. Bakhtin (1979/1992), no entanto contrapondo-se à lingüística clássica, chega à proposição de que o processo comunicativo está baseado na expressividade dos sujeitos falantes, do homem real que, ao comunicar, encontra-se no "momento inseparável em que o conteúdo e a forma se fundem" ( $p$. 403). Ambos dialogaram com a epistemologia moderna, com as ideias de Kant, com o marxismo, com a psicanálise e com a fenomenologia. 
A trajetória de vida e reflexão de cada um dos filósofos, entretanto, é muito diferenciada: Merleau-Ponty viveu na França, formou-se em filosofia na École Normale Supérieure (Paris), ao passo que Bakhtin passou sua vida inteira na Rússia, concluiu sua formatura, também em Filosofia e em Letras na Universidade de São Petersburgo. Bakhtin (cf. 1979/1992, 1934/2004) toma como foco para compreensão do processo comunicativo a análise de obras literárias que, de acordo com sua concepção, expressam a perspectiva do sujeito no mundo em seu esforço de articulação entre história e experiência carnal - tal como, por exemplo, em sua discussão sobre a obra de Rabelais (Bakhtin, 1934/2004, p. 206). Já Merleau-Ponty (1952/2004a), ao tratar da linguagem, toma como exemplo central a pintura. O filósofo francês tem no foco de suas reflexões a dimensão antepredicativa do processo comunicativo, a intercorporeidade e o processo perceptivo.

A justaposição das ideias desses dois pensadores nos leva a entender que, tanto a dimensão da intercorporeidade é um elemento importante para se pensar o processo comunicativo, quanto a noção de dialogismo é fundamental para se compreender a ação simbólica humana, em suas diversas facetas. Ao tratar da fronteira da relação eu-outro e eu-mundo eles desenvolveram noções calcadas em dualidades, ao invés de dicotomias: a noção de dialética sem síntese elaborada por Merleau-Ponty (1960/1980), e de dialogismo, desenvolvida por Bakhtin (cf. 1979/1992, 1934/2004), sustentam uma dimensão de tensão inerente à relação comunicativa/perceptiva. E se essas noções, desenvolvidas em contextos sociais tão diferentes (França e Rússia do século XX), encontram diversos pontos de tensão, parece haver também pontos de aproximação entre elas.

Também a trama em Lavoura arcaica (Carvalho, 2001/2005) é construída por núcleos de tensão e aproximação. A narrativa é uma espécie de releitura da parábola bíblica do filho pródigo. O narrador-personagem, André, sufocado pela carga de afeto da mãe e atado pelas leis rígidas do pai, vive uma relação incestuosa com Ana, sua irmã, e depois disso não vislumbra outra alternativa a não ser abandonar a casa da família. Então, Pedro, o primogênito, deixa a casa com a missão de resgatar o irmão - missão que cumpre com sucesso. No entanto, o retorno de André não pode ser pleno, mudanças irreversíveis parecem ter acometido aquela família. O romance se constroi pelo fluxo de memória de André: Lavoura arcaica é o olhar que ele, após ter vivido tudo aquilo, dirige à história de sua família.

Impactado com a leitura do romance, Luiz Fernando Carvalho (2001/2005). construiu sua própria obra. O diretor, em depoimento citado por Avellar (2007, p. 77) afirma ter-se reconhecido no texto de Nassar (2002) e que procurou criar uma resposta ao romance "que jamais nega a sua fonte, ao contrário, avizinha-se dela, porém o mais invisível possível". Coloca-se aqui, uma vez mais, a questão dos núcleos de tensão e aproximação: se, por um lado, o filme seria um retorno ao livro, por outro, é uma obra nova estimulada pelo romance, é verdade, mas que se faz por si própria.
Nessa direção, iniciaremos a exposição procurando estabelecer um diálogo entre os pensamentos de Bakhtin e Merleau-Ponty sob as dimensões do sensível e a linguagem, a gênese do sentido das expressões simbólicas e a temporalidade, selecionando alguns elementos-chave que servirão de suporte à compreensão de traços da obra literária e cinematográfica.

\section{O sensível e a linguagem}

Ao analisar o discurso expresso nas novelas, Bakhtin (1934/2004) critica o abstracionismo decorrente de análises que partem da separação entre estilo individual e os modos vivos e sociais de discurso; posto que a compreensão não pode ignorar que o discurso acontece no cotidiano das relações de uma subjetividade que o expressa. A produção de sentido implica um posicionamento no mundo vivido no qual o sujeito se expressa segundo o estilo que lhe é próprio, em sua relação com os outros. A palavra emerge em um diálogo vivo em relação com os discursos precedentes e em busca de uma resposta.

Na medida em que a significância linguística emerge da relação com o pano de fundo da linguagem, o significado de uma expressão é entendido na relação com outras expressões em torno de um tema. A orientação para o outro, destino de qualquer expressão, introduz a diferença de pontos de vista na relação.

A linguagem nunca é unitária/monológica porque é endereçada a alguém. A novela, na concepção de Bakhtin (1934/2004), é um hibrido, posto que contempla diversas linguagens e consciências de linguagens dentro de si. A linguagem e sensibilidade do mundo, expressas na novela, não aceitam o discurso único. O discurso (a não ser um discurso vazio) não se constitui senão em relação com a materialidade orgânica cujo suporte é ideológico. A expressão nasce, portanto, como uma construção híbrida. O estilo é a maneira com que a subjetividade articula as diversas linguagens, ou melhor:

"O estilo é o homem", dizem; mas poderíamos dizer:
o estilo é pelo menos duas pessoas ou, mais precisa-
mente, uma pessoa mais seu grupo social na forma
do seu representante autorizado, o ouvinte - o par-
ticipante constante na fala interior e exterior de uma
pessoa (Voloshinov \& Bakhtin, 1926/n.d., p. 18).

Bakhtin (1979/1992) discorda das soluções racionalistas e empiristas sobre as formas de se apreender o mundo. O empirismo supõe a autointeligibilidade do fenômeno empírico que supostamente poderia ser apreendido de maneira imediata. O racionalismo supõe a natureza da verdade como independente da experiência. Bakhtin (1979/1992), contrapondo-se a estas epistemologias modernas, assume que o homem constroi categorias para apreender o mundo e que esta apreensão se dá, sempre, em um dado contexto histórico por meio das ações concretas do sujeito. 
As reflexões de Bakhtin (1979/1992) dirigem-se à fronteira da relação eu-outro, entendida como o campo de alternância entre os sujeitos que se expressam. O diálogo como metáfora da relação eu-outro seria comparável à relação figura-fundo. Segundo as experiências dos teóricos da Gestalt, o que se torna 'figura' pode ser distinguido apenas em relação ao que se torna "fundo", o que indica a existência de uma tensão na fronteira do campo perceptivo.

A metáfora figurativa utilizada por Herbst (1995) para compreender o diálogo também é um sinal de que há aproximações possíveis entre a filosofia de Bakhtin e a fenomenologia da percepção de Merleau-Ponty (1945/1994). Ambos se afastam da noção de neutralidade epistêmica e da noção de representação mental como lócus da construção de conhecimento.

Para Merleau-Ponty (1952/2004a, p. 71): "Muito mais do que um meio, a linguagem é algo como um ser" Essa corporalidade da linguagem - esse "imenso tecido" - lhe confere ambiguidade: "A linguagem diz peremptoriamente quando renuncia para dizer a própria coisa" (Merleau-Ponty, 1952/2004a, p. 73). O filósofo refere-se aqui a um tipo peculiar de lógica; não aquela das ciências exatas senão uma lógica alusiva: a lógica das metáforas sensíveis. Com efeito, "como o tecelão, o escritor trabalha pelo avesso: lida apenas com a linguagem, e é assim que de repente se encontra rodeado de sentido" (Merleau-Ponty, 1952/2004a, p. 73). E esta "existência paradoxal está condenada ao modo de presençaausente - visível-invisível, intersensorial e intersubjetivo, união do múltiplo" (Frayze-Pereira, 2006, p. 187).

Nesse caso, são justamente as diferenças de linguagens que permitem a articulação da correspondência: a unidade do ser emerge da relação entre os diversos. O que se justifica pelo seguinte: "Se, por um lado, cada sentido abre-se para um mundo absolutamente incomunicável para os outros sentidos, por outro, está ligado a algo que, por sua estrutura, abre-se para o mundo dos outros sentidos constituindo com eles um único ser" (Frayze-Pereira, 2006, p. 164). Com efeito, a percepção não é a soma de dados visuais, auditivos. Ao invés disso, se dá de modo indiviso e fala simultaneamente a todos os sentidos (Merleau-Ponty, 1945/1994). A percepção é sinestésica.

Perceber, segundo a lógica científica, é operar em um mundo de coisas cujas propriedades são fixas e inalteradas. À medida que a coisa percebida é sempre igual a si mesma e unívoca em sua manifestação, o corpo funcionaria apenas como mediador entre a informação externa (unívoca em sua manifestação) e o aparato sensorial. A esse respeito, Merleau-Ponty (1960/2004b, p.13) é contundente: "A ciência manipula as coisas e renuncia a habitá-las". O que quer dizer com isso?

Segundo sua filosofia, homem e mundo estão intrincados ontologicamente: "Visível e móvel, meu corpo conta-se entre as coisas, é uma delas, está preso no tecido do mundo, e sua coesão é a de uma coisa" (Merleau-Ponty, 1960/2004b, p. 17). O corpo é uma coisa entre coisas. "Mas dado que se vê e se move, ele mantém as coisas em círculo ao seu redor, elas são um anexo ou prolongamento dele mesmo (...) e o mundo é feito do estofo mesmo do corpo" (Merleau-Ponty, 1960/2004b, p. 17) O que é sentido não é uma experiência do olhar ou da audição, mas é uma visão $e$ uma escuta do mundo.

A sensação e o sentir são uma modalidade da existência e não podem se separar do mundo (Caznok, 2003). É justamente o corpo inteiro, por meio dos múltiplos sentidos, que se comunica com o mundo:

corpo e coisa são tecidos de uma mesma trama: a trama expressiva do sensível. Nessas condições, delineia-se em paralelo uma teoria da expressão corporal e uma estética, considerando-se que o ato de expressão, isto é, a instituição do sentido que encontra sua origem em nossa corporeidade será comparável à realização propriamente estética que instaura a arte (Frayze-Pereira, 2006, p. 171).

Nessa medida, uma vez que a percepção fala simultaneamente a todos os sentidos, a lógica de toda obra de arte bem sucedida, vale dizer, é uma lógica que opera por alusão. Mas isso não significa que determinada obra "evoque" os demais sentidos; ela dá existência visível àquilo que ingenuamente se considerava invisível. Por exemplo, diante de uma pintura, não temos necessidade de sentido muscular para ter a voluminosidade do mundo, pois essa "visão devoradora" dá acesso à textura mesma do ser, textura que o olho habita como o homem sua casa (Merleau-Ponty, 1960/2004b).

Ao focalizar a percepção, Merleau-Ponty (1960/2004b) enfatiza as origens pré-verbais, antepredicativas da comunicação humana que compõem o sentido dessa comunicação. Da mesma forma, Bakhtin (1979/1992), a gênese do sentido se vincula a uma realidade transverbal comum entre os sujeitos falantes, em que o ato comunicativo emerge em associação com uma cadeia discursiva que o precede.

\section{Gênese do sentido}

Qualquer enunciado, por se dirigir a alguém, estabelece um elo real na cadeia de comunicação verbal, no interior de uma dada esfera da realidade humana ou vida cotidiana e ganha significação (precisão de sentido) em sua relação com esse elo (Bakhtin, 1979/1992). A expressividade do locutor na produção do enunciado destitui a neutralidade da palavra e da oração.

A inter-relação dos discursos não se vincula nem à sintaxe nem aos objetos de sentido, porém se refere à resposta de outrem, ao fenômeno de alternância entre os sujeitos falantes, marcado por uma dupla expressividade: a de quem fala e a de quem acolhe a fala. Bakhtin, portanto, afasta-se da noção de representação mental como cópia da realidade (cf. Marková, 2003/2006). Conforme o filósofo russo, a noção de verdade, nas ciências humanas, estaria ligada à possibilidade 
de "superar a alteridade do que é alheio sem transformar em algo que é pessoal" (Bakhtin, 1979/1992, p. 412). Trata-se de uma espécie de relação com o outro que Bakhtin desenvolve sob o rótulo de dialogismo.

O dialogismo de Bakhtin (1979/1992) se aproxima da fenomenologia husserliana (Sobral, 2005a, 2005b), que propõe o retorno às coisas mesmas e enfatiza os fenômenos como base do conhecimento do mundo humano. Segundo Sobral (2005b), as compreensões de Bakhtin caminham no sentido de integrar, filosoficamente, as dimensões de percepção do mundo natural e a construção do mundo social, "integração na qual o eu depende das relações com os outros, mas [o eu] não é entendido como paciente do agir dessas relações, mas como um agente que é por elas influenciado, mas também as altera, as ressignifica, dá-lhes feição" (p. 148).

A produção de sentido implica, portanto, posicionamento no mundo vivido. De acordo com Bakhtin (1934/2004), o discurso dialógico ideológico é estruturado segundo uma persuasividade interna que abre diferentes possibilidades de pensamento, sua significação demanda reorganização por quem o assimila. Sua estrutura semântica é aberta, viabilizando diferentes caminhos a se percorrer em sua significação, ainda que técnicas de balizamento e canalizações do leitor façam parte da expressão. Em contato com a heteroglossia do mundo e com a inevitabilidade do recorte pessoal, toda expressão será ideológica, o que na concepção de Bakhtin (1934/2004) significa dizer que o ponto de vista dos sujeitos, sempre situados, os conduz a diálogos insolúveis, imbricados em constantes ressignificações ou estilizações ao longo do tempo.

Para Merleau-Ponty (1969/2002), “o corpo é o veículo do ser no mundo" (p. 161) e o estilo é o jeito de o corpo se relacionar com as coisas. Mas não se trata apenas de um maneirismo; o que está implicado aqui é um vir a ser do sentido que, na verdade, remete-se a um escoamento de si a si. Esse escoamento pode ser entendido enquanto deformação coerente que caracteriza a estilização do mundo.

No texto "O cinema e a nova Psicologia", escreve o filósofo:

Cézanne dizia que era possível enxergar o aveludado, a dureza, a maciez e até o odor dos objetos. Minha percepção, então, não é uma soma de dados visuais, táteis ou auditivos: percebo de modo indiviso, mediante meu ser total, capto na estrutura única da coisa uma maneira única de existir, que fala, simultaneamente, a todos os meus sentidos (MerleauPonty, 1945/2003, p. 105).

No pensamento de Merleau-Ponty (1960/2004b), o olhar sobre o movimento de surgimento de algo se pauta pela articulação entre o visível e o invisível, e o vir a ser preexiste e amadurece em sintonia com sua incompletude. O corpo apresenta a reflexibilidade e a visibilidade. É esse corpo reflexivo que permite ao filósofo mostrar que a experiência do corpo e consigo próprio se propaga na relação com os outros e com as coisas: "é e faz sentido" (Chauí, 2008, p. 47).

"As coisas do mundo possuem interior, são fulgurações de sentido" (Chauí, 2008, p. 47). Nós e as coisas, interioridade que se exterioriza, somos feitos do mesmo estofo - da mesma carne. A experiência do mundo não decorre da ação das coisas sobre nossos órgãos do sentido e tampouco das ideias ou representações que fazemos delas. Porém, sendo feitos da mesma carne, corpo e mundo comunicam-se:

O olho vê o mundo, e o que falta ao mundo para ser quadro, e o que falta ao quadro para ser ele próprio, e, na paleta, a cor que o quadro espera; e vê, uma vez feito, o quadro que responde a todas essas faltas, e vê os quadros dos outros, as respostas outras a outras faltas (Merleau-Ponty, 1960/2004b, p. 19).

Percebemos, portanto, que Merleau-Ponty, assim como Bakhtin - ainda que por caminhos muito diferentes (cf. Voloshinov \& Bakhtin, 1926/n.d.) - destitui a noção de sujeito, pensamento, ou pessoalidade, como origem do sentido, ou seja, a posição subjetiva, isolada, não é determinante da produção de sentido. O sentido se encontraria no entrejogo eu e outro. De acordo com o filósofo:

As conseqüências da palavra, como as da percepção (e da percepção de outrem em particular), ultrapassam sempre suas premissas. Nós, que falamos, não sabemos aquilo que exprimimos necessariamente melhor do que aqueles que nos escutam (MerleauPonty, 1960/1980, p. 135).

A abertura para o que lhe é alheio delineia um movimento na subjetividade que pode ser compreendido como a própria passagem do tempo (Merleau-Ponty, 1945/1994). As análises de Merleau-Ponty e Bakhtin, acima discutidas, expressam como a experiência concreta no mundo vivido é marcada por coordenações e esforços em relação ao outro.

\section{A Temporalidade}

Ao provocar fissuras na carne do mundo, que é porosa, o corpo delineia uma perspectiva. Merleau-Ponty (1945/1994) vai dizer que o tempo existe justamente quando uma subjetividade vem quebrar a plenitude do ser em si. Assim, a cavidade onde o tempo se forma é marca dessa subjetividade. $\mathrm{O}$ mundo vivido é o mundo com significado:

Nós não dizemos que o tempo é para alguém: isso seria estendê-lo ou imobilizá-lo novamente. Dizemos que o tempo é alguém, quer dizer, que as dimensões temporais, enquanto se recobrem perpetuamente, se confirmam uma às outras, nunca fazem senão explicitar aquilo que estava implicado em cada uma exprimem todas uma só dissolução ou um só ímpeto 
que é a própria subjetividade. É preciso compreender o tempo como sujeito e o sujeito como tempo (Merleau-Ponty, 1945/1994, p. 565).

Passado, futuro e presente articulam-se em um movimento de temporalização, bem como as diversas marcas de que somos feitos coadunam-se em um único corpo. Posto que passado e futuro se expressam no presente, o embate entre o novo e o velho é fundante da subjetividade que irrompe. Mas, assim como no tempo, para que seja subjetividade, é preciso que se abra para um outro e saia de si, isto é, transcenda.

Com efeito, dizer que somos feitos da mesma carne não implica que existamos à semelhança uns dos outros e das coisas. Pelo contrário, a carne é marcada por infinitas fissuras, dobras, aproximações e afastamentos; como vimos, a experiência do corpo se propaga na relação com os outros e com as coisas. Esta transição de um presente para outro presente é a própria subjetividade. Portanto, compreendido entre as duas margens, o porvir e o antigo, o tempo é o escoamento de si para si mesmo. Somos tempo: visível-invisível, som e silêncio, diversidade e unidade do múltiplo.

As análises de Bakhtin (1934/2004) sobre as novelas que emergiram após o renascimento destacam mudanças de efeito temporal em relação às produções anteriores. Ele compreende que a entrada do sujeito em um mundo marcado pela polifonia, internacionalização e com múltiplas relações produz efeitos sobre si e suas expressões criativas. As novelas modernas, por exemplo, são marcadas pelo contato intenso com o presente e sua abertura para novidades na realização multilinguística. A novela estabelece o contato com um presente inconcluso e espontâneo. Quanto mais se caminha em direção ao futuro, mais inconcluso permanece. Bakhtin (1934/2004) associa essa idéia à noção de progresso da modernidade, e sua compreensão de tempo, do passado ao futuro. O caráter inconcluso dessas produções é o que mantém o impulso para se continuar até o fim. Na modernidade o indivíduo ganha a possibilidade de estabelecer uma iniciativa necessária para a promoção de transformações em sua época.

A limitação e insuficiência de um ponto de vista, contudo, são apresentadas na novela como algo historicamente relativo criticado pela obra. Essa crítica se faz pelo sistema interanimado de linguagens interconectadas dialogicamente. A interanimação não é feita a partir de uma abstração lingüística, mas a partir de imagens dos diferentes pontos de vista em movimento, ou seja, dos seres viventes e ativos que agem num enquadre concreto. Imagens de linguagens, estilos e consciências que não apenas se expressam, mas que também se criticam mutuamente (Bakhtin, 1934/2004).

Para esses autores, portanto, tempo e espaço não são tomados como transcendentais, mas como formas da realidade imediata. Não se trata da concepção de um tempo cronológico dividido em datas, horas, minutos e segundos, mas das transformações que se dão na relação do sujeito com os outros.
Assentados nas discussões apresentadas ao longo dessa primeira parte do texto, em que, tratamos da articulação entre as dimensões sensíveis e a linguagem, apresentaremos agora uma discussão sobre as articulações em Lavoura arcaica, romance e filme. Temos em vista que, tal qual o diálogo proposto entre Bakhtin (1934/2004) e Merleau-Ponty (1952/2004a), a descrição das obras e discussão de alguns de seus aspectos partem do olhar dos pesquisadores, que os colocam em horizontes de compreensão contextualizados ao longo do processo de investigação.

\section{Literatura e cinema: a unidade dos sentidos em Lavoura arcaica}

Procuraremos nos posicionar, em nossas reflexões sobre o romance e o filme, a respeito das diferenças de linguagens que permitem a articulação da correspondência, quer dizer: a unidade do Ser que emerge da relação entre os diversos. Para começar nossa exploração das obras, vejamos o que disse o cineasta Luiz Fernando Carvalho (2001/2005), em depoimento sobre a criação do filme, a partir de sua leitura do romance Lavoura arcaica:

Primeiro eu li o Lavoura... visualizei o filme pronto, quando cheguei no final eu já sabia o filme - eu tinha visto um filme, não tinha lido um livro. Porque aquela poética é de uma riqueza visual impressionante, então eu entendi a escolha daquelas palavras que, para além de seus significados, me propiciavam um resgate, respondiam à minha necessidade de elevar a palavra a novas possibilidades, alçando novos significados, novas imagens. Tentei criar um diálogo entre as imagens das palavras com as imagens do filme. Palavras enquanto imagens (Carvalho, 2002, p. 35).

O texto de Lavoura arcaica é todo construído por metáforas sensíveis. A leitura do cineasta parece apontar nessa direção. Fala em "imagens das palavras" e no resgate que lhes propiciam. Seus olhos captam no avesso daqueles signos toda a sua potência visual; potência que o lança na construção do filme, sempre em diálogo com as imagens das palavras.

O romance é dividido em duas partes: "A partida" e "O retorno". O texto acontece entre a partida e a volta de André, a narrativa transcorre entre essas duas margens, ou melhor, ela é o escoamento dessas margens, uma em direção à outra. Mas as margens são palavras e por meio delas, tomam a forma de duas festas: uma no início do romance e outra no fim. No dia seguinte à volta de André, já na parte final da história, a família realiza uma grande festa. E o trecho do romance que corresponde a esta festa praticamente repete palavra por palavra, a passagem sobre o início festa que acontecia aos domingos e servia como alegoria da união da família.

Em um capítulo da primeira parte do livro, em que André traz suas memórias no âmbito da família, há a narração da primeira festa. Há muitas pessoas - parentes, vizinhos, 
amigos - que, tão logo o cheiro de carne assada se perde entre as árvores, se juntam para uma grande roda de dança. À união das pessoas, sempre ao ritmo da música soprada por uma flauta, se contrapõe a posição de André, que assiste a tudo afastado, camuflado por entre as árvores. Esta união, com a qual André já se relaciona de maneira muito peculiar - observando à distância - serve como emblema da força da família. Mesmo porque não se trata de uma festa isolada. Toda a passagem é construída de modo a transmitir ao leitor que se trata de uma situação que se repete.

Os verbos das orações se conjugam no pretérito imperfeito: o passado da ação continuada. Ou seja, é o retrato do tempo em que a família era unida, a estrutura familiar se perpetuava, enfim, toda a ordem apregoada pelo pai se alimentava da repetição mesma daquela estrutura.

No filme, a tomada inicial, na primeira festa, se dá a partir da perspectiva de André, que assistia à distância. A câmera, se não é o olho dele do ponto de vista da óptica, o olho físico, representa metaforicamente o seu olhar. O plano que vai se expandindo, sempre para além dos limites do quadro, é emblema da amplitude de sua visão. Trata-se da maneira peculiar com que André se relaciona diante da suposta união da família. Se por um lado ele é o protagonista da história que conta; por outro, ele é também aquele que a contempla e, nesse sentido, reflete a todo tempo sobre aquilo que viveu. Para marcar essa distinção, no filme, a voz em off - do narrador que reflete - não é a de Selton Mello ator que interpreta André -, senão a voz do próprio diretor, Luiz Fernando Carvalho (2001/2005). No entanto, André ainda não havia partido - pois fazia parte daquela estrutura. Por isso, há na seqüência, alguns cortes que o mostram de corpo inteiro, além de outras tomadas que evidenciam sua inserção, sua pertença, ainda que diversa, àquela estrutura familiar. A sequência da dança de Ana é um jogo alegre e suave de sombra e luz. Ela cumpre à risca o seu papel ao fazer par com o primogênito e dançar com candura. Mas há também toda uma sensualidade - em larga medida, se mostra para André. Os planos, em que as imagens dos irmãos são contrapostas, captam a força que há entre eles; força que, no limite, se expressa no corpo e pelo corpo de André, cuja reação será se misturar à terra e se cobrir de folhas. Mais uma vez, há aqui o jogo de opostos, as duas margens de que falamos há pouco: nesse caso, todo o ímpeto de vida de Ana e o retorno, alusivo da morte, de André à terra.

Esse retorno de André à terra encontra sua expressão máxima no incesto que viria a ser consumado com a irmã, Ana. Mas, se por um lado o incesto é expressão de sua contestação face à família, por outro, o ato amoroso vivido com Ana marca o retorno radical às profundezas da família. Em vez de o corpo irromper para fora, para o mundo, para a cultura, o que há é a recusa da alteridade; o corpo permanece imerso no caldo familiar. Sua contestação toma o caminho da conservação.

\section{Incesto}

Debrucemo-nos, então, com um pouco mais de cuidado sobre o que talvez seja o evento mais significativo para a trama: o incesto. Como explicitamos no início, ao tomarmos o tempo como um escoamento de si para si mesmo, concebemos que esse escoamento é mediado pelo corpo que vive experiências de fissuras, dobras, aproximações e afastamentos. No livro, as diabruras que faz o tempo são atemorizantes:

O tempo, o tempo é versátil, o tempo faz diabruras, o tempo brincava comigo, o tempo se espreguiçava provocadoramente, era um tempo só de esperas, me guardando na casa velha por dias inteiros; era um tempo também de sobressaltos, me embaralhando ruídos, confundindo minhas antenas, me levando a ouvir claramente acenos imaginários, me despertando com a gravidade de um julgamento mais áspero, eu estou louco! e que saliva mais corrosiva a desse verbo, me lambendo de fantasias desesperadas, compondo máscaras terríveis na minha cara, me atirando, às vezes mais doce, em preâmbulos afetivos de uma orgia religiosa (Nassar, 2002, p. 95).

O tempo corta André, vara-o por dentro. Provoca confusões, traz a loucura. Sorrateiro, o tempo, como o leito de um rio traiçoeiro, traz a irmã para a porta da casa velha da família, local em que o ato amoroso proibido será consumado. Na trama do Lavoura arcaica, o evento do incesto ao mesmo tempo em que fratura dois momentos da trama, é também o elo de ligação entre eles. Experiência paradoxal na qual a afirmação da unidade - tentativa de fusão no seio da família e tentativa manutenção de sua endogamia - implica ruptura, destruição da própria família. Ao mesmo tempo em que este acontecimento permite reflexão, distanciamento, elaboração simbólica, transformação pessoal e a própria passagem do tempo, permite também a constituição de uma narrativa que traz às cenas imagens dos momentos marcantes estilizadas pelo autor (na voz do próprio personagem).

De dentro da casa velha, enquanto André espreita a aproximação da irmã, o tempo forja mais uma armadilha: transforma-se em poesia. Aos olhos do irmão, Ana é a pombinha da infância. Aquele animalzinho, "branco branco o rosto branco", que ele - "era uma ciência de menino" - está prestes a reter:

No centro da armadilha; numa das mãos um coração em chamas, na outra a linha destra que haveria de retesar-se com geometria, riscando um traço súbito na areia que antes encobria o cálculo e a indústria; nenhum arroubo, nenhum solavanco na hora de puxar a linha, nenhum instante de mais no peso do braço tenso (Nassar, 2002, p. 100). 
A narrativa, de um só jorro, empreende deslocamentos espaciotemporais de ampla magnitude - pródigos em lirismo. No entanto, conforme admite o próprio narrador, essas "fantasias desesperadas" compõem "máscaras terríveis". Máscaras reais: a fantasia do menino se concretizará no ato a ser consumado com a irmã. É o que se revela no capítulo seguinte: "e foi numa vertigem que me estirei queimando ao lado dela, me joguei inteiro numa só flecha, tinha veneno na ponta desta haste" (Nassar, 2002, p. 103). A vertigem ocorre tanto no nível do discurso quanto no da sexualidade: a "saliva corrosiva" do verbo se corresponde com o "veneno na ponta" da haste. A consciência do amor impossível o faz pedir a Deus, por meio de uma prece na qual embaralha o sagrado e o profano, que the conceda um milagre.

Percebemos, portanto, nas estilizações discursivas, mudanças de efeito temporal. Ao narrar o incesto André não apenas descreve como discute o acontecimento, posiciona-se diante dele de diferentes maneiras. Encontramos na novela de Raduan Nassar (2002) a entrada do sujeito em um mundo marcado pela polifonia, contato intenso com o presente e sua abertura para novidades na realização multilinguística. Entra em jogo uma complexa rede dialógica, em torno do incesto. Diante do irmão Pedro, que é capaz de oferecer um suporte às memórias comoventes de André, os discursos sobre o incesto puderam transitar pelas diferentes posições que André diante de sua irmã, a memória retroage à infância, onde o protagonista reconhece o nascimento e a permanência de uma unidade de sensações em relação à sua família. Reconhece também os limites e a impossibilidade de uma completa fusão. A rebeldia emerge de uma frustração pela impossibilidade de fazer corresponder o discurso do pai e a experiência do corpo.

Com efeito, o incesto, no romance, parece simbolizar o horror à diferença vivido por André, que ainda estaria imerso ao caldo familiar. Seu corpo não teria irrompido para a cultura, mas - às avessas - ele se ramificaria para dentro, oco, preso ainda ao ventre materno.

E no filme, como é tratado o incesto? Na obra de Carvalho (2001/2005), a ligação de André à mãe é tratada com muito lirismo e a angústia decorrente, que se apresenta no romance, parece amortecida. Vejamos, então, em que sentidos essas forças se articulam no que diz respeito ao plano estético sobre o qual o incesto é construído. Mas, para isso, precisamos da leitura desse evento tal como se mostra na obra de Carvalho (2001/2005). Vamos a ela.

André está na casa velha. Aflito, parece procurar alguém. A câmera habita a casa, mas não acompanha o protagonista todo o tempo: vê-se o silêncio, sente-se o vazio. Após se deslocar lateralmente pelos cômodos, a câmera encontra André, no fundo do quadro, caído e dizendo: "estou louco". Segue um plano predominantemente escuro (de dentro da casa), com frestas de luz (vindas do lado de fora). A câmera se aproxima da fresta lentamente, do outro lado, está Ana. Há, então, um corte para André menino, que observa da mesma janela. Entra a trilha sonora característica das cenas da infância, a luz se veste de um dourado mais forte e, no mesmo lugar em que se encontrava a irmã, aparece agora uma pomba. Os olhos do menino (que espreita) se confundem com os olhos do jovem adulto; a pomba, com Ana.

André regozija-se com a presença da irmã. Festivo, corre para dentro da casa e atira para o alto um punhado de feno. Em seguida, há um plano lento com as partículas de palha flutuando, que é alusivo de plenitude. Mas um corte revela que Ana não está mais lá. Entra uma trilha mais severa e o discurso de André sobre o tempo na voz over do narrador. O tempo versátil que faz diabruras, que não perde a oportunidade para dar o bote. Enquanto isso, a câmera passeia uma vez mais pela casa velha. Mas, desta feita, atenta aos primeiros planos, ela caminha pelas paredes - por sua estrutura. Ao esqueleto da casa, soma-se o esqueleto de André: close de sua mão tocando a parede.

O olhar encontra, novamente, Ana. Um plano da porta principal da casa velha (de dentro para fora) traz a irmã bem no centro. Um corte mostra André menino segurando a linha e prestes a capturar a pomba. Os irmãos ficam vis-à-vis por alguns instantes. Ana enfim adentra a casa - André bate a porta - o menino captura a pomba. Entra a trilha das cenas da infância, mas em um formato ainda mais lírico. Ana deita-se no andar de baixo. André corre em sua direção. $\mathrm{O}$ menino dispara em direção da arapuca em que capturou a pomba. $\mathrm{Na}$ casa velha, segurando as mãos da irmã, André pede a Deus que lhe conceda viver aquela paixão. Cortes introduzem detalhes da pena da pomba (como se fossem detalhes da mão de Ana). Por fim, diz à irmã, que juntos iriam incendiar o mundo. Em um momento raro, Ana sorri. A tela fica clara, aparece o menino correndo com a sua pomba e a gritar: "é minha, é minha!". Ele a beija e a deixa voar. A câmera acompanha a pomba no céu.

As "máscaras" que as fantasias de sons e imagens produzem não parecem tão "terríveis" como as que se desenham na página impressa. Os eventos narrados no livro são mais chocantes. No filme, as cenas da consumação do incesto são diluídas pela "luz boa da infância". Como nas sequências com a mãe, a angústia fica relegada aos momentos em que André rememora - ou se refere a - os fatos. No texto de Raduan Nassar (2002), não há essa cisão. Dizendo de outra maneira, a amplitude espaciotemporal se apresenta de forma mais coesa no romance e mais fragmentada no filme. Há, no livro, um equilíbrio entre as condições assumidas por André: narrador e personagem são, concretamente, um só. O plano do conflito (personagem) e plano da reconciliação (narrativa) estão interligados.

O discurso paterno continha um elemento invisível desde a perspectiva de quem o pronunciava. Entretanto, André era sensível a este discurso e se apropriou de sua força argumentativa, ainda que paradoxal, endereçando-se para a realização de um ato sabidamente proibido.

No filme, as múltiplas posições em relação ao conflito são desmembradas: há o André em cena, vivido por Selton Mello, e a narração de Luiz Fernando Carvalho (2001/2005), 
o André que rememora. Dessa forma, enquanto o livro apresenta o plano do conflito e o da reconciliação em relação de equilíbrio, a obra de Carvalho (2001/2005) prioriza o plano da narrativa reconciliada. $\mathrm{E}$, assim, a dimensão trágica do incesto acaba amortecida no filme. O paradoxo vivido por André, contudo, sustenta-se em ambas as obras: logo após se recuperar da relação amorosa com sua irmã, André a procura, tentando convencê-la a prosseguir um projeto endogâmico que, em suma, continua o projeto familiar do pai. Neste momento, produz um discurso persuasivo, mas que é frustrado pela resposta negativa da irmã (melhor dizendo, pela insistência dela em não respondê-lo).

A percepção da diferença no outro (Ana) o conduz a uma mudança no discurso, que neste momento torna-se cada vez mais agressivo, convencendo-o a partir, definitivamente.

André sente a negativa da irmã como uma mutilação, como se fosse arrancado do ventre - do qual ainda não se libertou. A interdição imposta por Ana é, para ele - eterno prisioneiro do seu objeto -, a morte. Então, a fim de sobreviver, ou melhor, livrar-se da morte, o narrador-personagem deixa a casa. Ocorre que, uma vez mais, a geometria barroca do destino se interpõe. Ora, no projeto de André, não existe sobrevivência se não houver família. É por isso que sua mochila vai pesada: é a família que carrega nas costas. Realmente, não é em busca de aventuras que ele parte, mas para manter acesa sua chama canhestra da vida.

André não consegue deixar plenamente a família, carregando-a com todo seu peso, como também sua família não consegue deixá-lo. Como esforço no sentido de preencher a lacuna da ausência de André (inquietante, causadora de sofrimento na mãe, pai e irmãos), Pedro se lança em busca do irmão, fazendo-o retornar. O retorno é marcando por intensa alegria, mas também cobranças. Entretanto, uma nova festa é organizada no dia seguinte à sua chegada.

\section{Segunda festa}

Mudanças irreversíveis acometeram aquela família. A volta de André já não pode ser plena: a dança não é mais tão bem marcada; Pedro, o irmão, está taciturno; Ana invade a festa endiabrada; e André também não é o mesmo. No livro, as palavras praticamente repetem a passagem do início, mas os verbos, como vimos, estão conjugados no passado da ação acabada: o pretérito perfeito. A alteração do tempo verbal, aqui, traz consigo uma potência reveladora. Passemos pelo trecho correspondente do filme.

Neste momento, a câmera é o olho de André, está na perspectiva dele. Mas desta vez Pedro, o irmão mais velho, entra em quadro. Sua postura taciturna, sombria - porque ele sabia do segredo do incesto entre os irmãos - é captada pela câmera, simbolicamente o olho de André. Quer dizer, a dança está lá em segundo plano - a presença sombria de Pedro vem "antes", no primeiro plano. Até que sai de quadro e há nova tomada da dança. No entanto, rapidamente, ocorre outra ruptura: é a presença endiabrada da irmã Ana, com quem houve o incesto, que demonstra em ato, em gesto, mudanças provocadas na estrutura daquela família depois da partida de André. O cineasta opta por várias tomadas (cortes dentro do plano) para marcar bem o caráter findo do tempo. Além disso, para mostrar que aquela família estava por um fio, o diretor não mostra André de corpo inteiro nesta seqüência final. Diferentemente da cena do início, ele já não é mais parte daquela estrutura. A precipitação de seu corpo é, aqui, a alteração do tempo verbal: ao equilíbrio entre luz e sombra de antes, agora o movimento caminha para a verticalidade da tragédia. Tanto que o primogênito uma vez mais entra em quadro, e revela o segredo ao pai. Por seu turno, o pai, sempre a voz da razão, associado à luz, se verte pela primeira vez em sombra. Ele também se endiabra. É justamente o patriarca, que sempre apregoava em seus pesados sermões a ordem e a união, quem vai efetuar o primeiro golpe concreto em direção à dissolução da família, ao seu trágico desfecho. E isso é emblema de que a volta de André não pôde, e não pode, ser perfeita, ser plena.

Essa circularidade da obra - a partida, o retorno, a festa do começo e a do fim do livro narradas praticamente pelas mesmas palavras - é uma circularidade que aponta, na verdade, para uma volta em espiral. Volta que deixa para trás muita dor, mas também saudades. A dor de André é, sobretudo, a dor do tempo, porque o tempo é marcado pelo embate entre o novo e o velho. A cavidade onde o tempo se forma é marca da subjetividade (Merleau-Ponty, 1945/1994); no nosso caso falamos da subjetividade de André, o narrador do romance. Mas de onde ele fala?

André resolve reunir os estilhaços do que restou de sua história em um romance. Após ter vivido a tragédia que assolou sua família, ele não consegue se despregar daquela estrutura. Estrutura, diga-se, contra a qual ele se insurge. Este é o paradoxo que André vive ao limite. Quer dizer, ele é o filho que parte, mas volta; desafia o pai, mas cede; escancara o discurso hipócrita de união da família, mas reclama os direitos de seu corpo justamente no incesto concretizado com a irmã. E, finalmente, sofre a dor de um tempo impiedoso, mas revive este tempo, ou melhor, vive pela primeira vez de novo a sua história ao reabrir o tempo, mergulhar em sua jornada e reuni-la em um texto; e o faz movido pela saudade, coerente à sua estrutura, porque, uma vez que vivia a unidade do múltiplo ao limite, compreendemos que André escoava de uma margem à outra: ele era essas margens.

Em Lavoura arcaica, o trágico e o lírico se fundem. Cada letra é carregada de sentidos. André e, por extensão, a narrativa trazem ao limite as marcas da ambigüidade: "um jogo alegre e suave de sombra e luz". Visível e invisível intrincados no corpo do texto. A tensão permanente entre visível e invisível é característica da relação eu-outro, no caso, relação de André com seu pai e os valores da família. Na cena imediatamente anterior à segunda festa, André retoma o discurso de seu pai sobre o tempo. Ambos trazem o tempo enquanto uma entidade poderosa em suas reflexões. A diferença é que, para o pai, o respeito ao tempo é algo que se pode controlar por meio da razão, da sabedoria, enquanto André trata de mostrar que o tempo pode ser um algoz, 
impiedoso em sua velocidade, mais versátil do que qualquer pensamento racional.

$\mathrm{Na}$ linguagem do cinema, em virtude das relações produzidas a todo instante pela sucessão de imagens, as relações entre visível e invisível são preponderantes (Xavier, 2003). Os estilhaços que o narrador em Lavoura arcaica costura em um texto são fortemente visuais e também dinâmicos. Mais uma vez cabe trazer o depoimento de Luiz Fernando Carvalho (2001/2005), que diz ter sempre pensado o livro "como uma daquelas pinturas islâmicas em cerâmica, normalmente pinceladas sobre superfícies singulares (...) onde a cada instante, quase desapercebidamente, surgisse um animal, uma flor, e você pudesse escolher um ramo novo para seguir" (Carvalho, 2002, p. 68).

A compreensão da produção estilística nas novelas, segundo Bakhtin (1934/2004, p. 50), passa pelo estudo "das imagens específicas de linguagens e estilos, a organização dessas imagens, sua tipologia (que pode ser extremamente diversa), a combinação das imagens das linguagens na totalidade da novela, as trocas e transferências de linguagens e vozes, suas inter-relações dialógicas". A propósito da produção cinematográfica, lembra-nos Merleau-Ponty (1945/2003) em $O$ cinema e a nova Psicologia, o filme não é mera soma de imagens senão uma forma temporal. Assim, é a sucessão de imagens que cria uma nova realidade. Bem como André costura os estilhaços de sua história em um romance, é também ele que, no filme (voz em off), após ter vivido a tragédia, dirige e monta a seqüência de cenas. Daí a pertinência de a voz em off, o narrador que "monta" a história, ser a do próprio diretor.

\section{Considerações finais}

Por meio da seleção de momentos da narrativa de $L a$ voura arcaica e sua articulação com o cinema, vimos o mergulho de Luiz Fernando Carvalho (2001/2005). no universo dos sentidos impregnado no texto de Raduan Nassar (2002) e seu voo até a montagem do filme. Interessante ressaltar, que o cineasta rechaça a noção de adaptação. Realmente, pudemos perceber que a pluralidade dos sentidos, tão bem explorada no filme, é anteriormente marca do romance, ainda que alusiva ou invisível. Como sugere Frayze-Pereira (2006), “o invisível não é negação do visível, pois está no visível como seu horizonte e seu começo, como seu inconsciente óptico" (p. 166). Ao trazer o livro para dentro de seus olhos, o filme não o repete, mas funda uma nova leitura, que parte das palavras do romance e a elas procura retornar. O retorno, contudo, não pode ser pleno. O novo ser, extensão do antigo, conserva algumas marcas, modificam outras. A semente do velho jamais perece, se debruça sobre o vir a ser. Passado e futuro ora se aproximam, ora se afastam, mas sempre se comunicam naquilo que nomeamos presente. Sem embate, não há tempo, não há outro, não há nada.

A diversidade e unidade do múltiplo, que percebemos no âmbito das narrativas, também se delineiam na correspondência entre as linguagens. Isto significa que se, por um lado, livro e filme se distanciam em alguns aspectos, por outro, estão inegavelmente ligados a uma mesma estrutura, a tragédia rememorada por André. No entanto, essa ligação não pressupõe uma uniformidade. Houvesse o acordo total que em determinados momentos o depoimento de Luiz Fernando Carvalho (2001/2005) parece apregoar, então não haveria comunicação entre as obras. E, neste caso, teria o filme existido?

Ao propor o retorno radical ao livro, o discurso do cineasta reveste-se de tonalidades incestuosas. Porém, ao realizar um filme que se corresponde com a obra de origem - não a repete - Carvalho (2001/2005) se liberta das amarras do incesto. Portanto, a unidade complexa - reconciliação e conflito, passado e futuro, reunião e exclusão, lirismo e tragédia - não alude exclusivamente aos encontros, à plenitude, mas contempla também o irrealizável, o trágico. O que isso significa? Ora, agrupar é, em maior ou menor medida, excluir. Nessa tensão - por vezes diabólica - é que podem ocorrer as mudanças, movimento. Há algo que nos faz, depois de ter partido da palavra ao universo dos sentidos, retornar à palavra. Retorno, se levado ao limite, ao título do romance, cuja força talvez não apreendamos de imediato. "Lavoura" remete ao futuro, ao porvir; "arcaica", ao antigo, àquilo que vem antes de tudo. Podemos então traduzir Lavoura arcaica pela expressão porvir que vem antes de tudo. Fecundar a lavoura é empreender ressignificações: lançar-se de volta ao porvir. O retorno para si-mesmo, na acepção de Bakhtin (1934/2004), tem o sentido de uma tentativa de integração do eu face à ruptura provocada pelo contato com o outro (Guimarães \& Simão, 2007; Sullivan, 2007). Os eventos que os personagens vivem na narrativa revelam experiências de construção de pontos de vista na relação com um ambiente simbolicamente heterogêneo. $\mathrm{O}$ autor, e podemos dizer que também o leitor, se apropria dos diversos discursos dos personagens - sempre situados uns em relação aos outros - de modo a elaborar ativamente uma compreensão e um discurso internamente persuasivo para si e para os outros. Todo discurso é expresso por alguém que tematiza fatos singulares de um ponto de vista próprio. Os personagens, por exemplo, não apenas se movem no espaço, mas falam e discutem os sistemas de crenças em questão, ou seja, posicionam-se e reorganizam-se subjetivamente em meio a uma multiplicidade: continuam os mesmos, porém transformados.

Concebemos o modo como se realiza o processo de integração dos sentidos, ou constituição da unidade do múltiplo, em conformidade com o movimento de retorno, bem como de partida, da qual ele depende. Ao percebermos na narrativa de André seu esforço para dar sentido às suas experiências no seio familiar - fazendo emergir, entre outras coisas, dois momentos festivos com significações marcadamente diferentes - visualizamos nele, enquanto personagem, um processo de mudança. Os processos de integração dos sentidos e mudança, por sua vez, se sustentam enquanto potencialidades dos acontecimentos precedentes, de um contexto que o viabiliza. Compreendê-los como característico do vir a ser subjetivo, da emergência de algo, exige que permaneçamos numa região 
intermediária em que o momento seguinte não é previsível a partir do anterior, mas plenamente realizável a partir dele.

Atentar-se a essa zona fronteiriça é o que nos ensinam as proposições filosóficas de Bakhtin (1934/2004) e MerleauPonty (1945/1994). Ambos não propuseram uma indistinção entre passado e futuro, eu e outro, ao invés disso, constataram sua co-existência irredutível, com suas margens, onde habita o significado da experiência. Entre o sensível e a linguagem, tal qual propomos no título do texto, diz respeito a essa zona intermediária da qual emergem as produções humanas. Dito de outro modo: entre a sensibilidade que um autor expressa em seu texto e faz mobilizar as câmeras de um cineasta, vemos emergir um filme, com expressividade própria, como também em dívida com relação às suas origens. Como diz André:

Não importava que eu, erguendo os olhos, alcançasse paisagens muito novas, quem sabe menos ásperas, não importava que eu, caminhando, me conduzisse para regiões cada vez mais afastadas, pois haveria de ouvir claramente de meus anseios um juízo rígido, era um cascalho, um osso rigoroso, desprovido de qualquer dúvida: "estamos indo sempre para casa” (Nassar, 2002, p. 35).

\section{Referências}

Avellar, J. C. (2007). O chão da palavra: Cinema e literatura no Brasil. Rio de Janeiro: Rocco.

Bakhtin, M. M. (1992). Estética da criação verbal (M. Pereira, Trad.). São Paulo: Martins Fontes. (Original publicado em 1979)

Bakhtin, M. M. (2004). Discourse in the novel. In M. M. Bakhtin (Ed.), The dialogic imagination (pp. 259-422). Austin: University of Texas Press. (Original publicado em 1934)

Carvalho, L. F. (Diretor). (2001/2005). Lavoura arcaica [DVD]. Rio de Janeiro: Riofilme.

Carvalho, L. F. (2002). Sobre o filme Lavoura arcaica. São Paulo: Ateliê Editorial.

Caznok, Y. B. (2003). Música: Entre o audivel e o visivel. São Paulo: Unesp.

Chauí, M. (2008). Merleau-Ponty: A obra fecunda. Revista Cult, 11 (123), 44-53.

Frayze-Pereira, J. A. (2006). Arte, dor: Inquietudes entre estética e psicanálise. São Paulo: Ateliê Editorial.

Guimarães, D. S., \& Simão, L. M. (2007). Intersubjetividade e desejo nas relações sociais: $\mathrm{O}$ caso dos jogos de representação de papéis. Revista Interacções, 30 (3), 3054. Recuperado em 01 maio 2009, de http://nonio.eses. $\mathrm{pt} /$ interaccoes/verartigo.asp? $\operatorname{cod}=67$

Herbst, D. P. (1995). What happens when we made a distinction: An elementary introduction to co-genetic logic. In T. Kindermann \& J. Valsiner (Eds.), Development of person-context relations (pp. 67-79). Hillsdale: Lawrence Erlbaum.
Marková, I. (2006). Dialogicidade e representações sociais: As dinâmicas da mente (H. M. Filho, Trad.). Petrópolis: Vozes. (Original publicado em 2003).

Merleau-Ponty, M. (1980). Sobre a fenomenologia da linguagem (Chauí, M. S., Trad.). In M. Merleau-Ponty (Org.), Os Pensadores (2a ed., pp. 129-140). São Paulo: Abril cultural. (Original publicado em 1960)

Merleau-Ponty, M. (1994). Fenomenologia da Percepção (C. A. Moura, Trad.). São Paulo: Martins Fontes. (Original publicado em 1945)

Merleau-Ponty, M. (2002). A prosa do mundo (P. Neves, Trad.). São Paulo: Cosac Naify. (Original publicado em 1969)

Merleau-Ponty, M. (2003). O cinema e a nova Psicologia (J. Grunewald, Trad.). In I. Xavier (Org.), A experiência do cinema (pp. 103-117). Rio de Janeiro: Graal. (Original publicado em 1945)

Merleau-Ponty, M. (2004a). A linguagem indireta e as vozes do silêncio. In M. Merleau-Ponty, O olho e o espirito (pp. 67-119, P. Neves \& M. Pereira, Trads.). São Paulo: Cosac Naify. (Original publicado em 1952)

Merleau-Ponty, M. (2004b). O olho e o espírito (pp. 67-119, P. Neves \& M. Pereira, Trads.). São Paulo: Cosac Naify. (Original publicado em 1960)

Nassar, R. (2002). Lavoura arcaica. São Paulo: Companhia das letras.

Sobral, A. (2005a). Ato/atividade e evento. In B. Brait (Org.), Bakhtin: Conceitos-chave (pp. 11-36). São Paulo: Contexto.

Sobral, A. (2005b). Filosofias (e filosofia) em Bakhtin. In B. Brait (Org.), Bakhtin: Conceitos-chave (pp. 123-150). São Paulo: Contexto.

Sullivan, P. (2007). Examining the self-other dialogue through 'spirit' and 'soul'. Culture \& Psychology, 13(1), 105-128.

Voloshinov, V. N., \& Bakhtin, M. M. (n.d.). O discurso na vida e o discurso na arte (C. Tezza, Trad.). Recuperado, em 05 maio 2009, de http://www.linguagensdesenhadas. com/imagens/03textos/autores/Bakhtin_Discurso_na_ vida.pdf. (Original publicado em 1926.)

Xavier, I. (2003). O olhar e a cena. São Paulo: Cosac Naify.

Renato Cury Tardivo é Professor da Faculdade de Psicologia da Universidade São Marcos, campus Tatuapé.

Danilo Silva Guimarães é Doutor pelo Programa de Pósgraduação em Psicologia Experimental do Instituto de Psicologia da Universidade de São Paulo.

Recebido: 02/10/2008

$1^{a}$ revisão: $20 / 11 / 2008$

$2^{a}$ revisão: $19 / 04 / 2009$

Aceite final: 22/05/2009 